\title{
The Integration of Submicroscopic Representations Used in Chemistry Textbook Sets into Curriculum Topics
}

\author{
Špela Hrast ${ }^{\star}$ and Vesna Ferk Savec \\ Faculty of Education, University of Ljubljana, Kardeljeva ploščad 16, 1000 Ljubljana, Slovenia \\ *Corresponding author: E-mail: spela.hrast@pef.uni-lj.si
}

Received: 21-06-2017

\begin{abstract}
To support the understanding of chemistry concepts and processes at the particulate level, various representations are included in learning materials. This paper focuses on how submicroscopic representations (SMRs) are integrated into Slovenian chemistry textbook sets with respect to the curriculum topics for 8th and 9th Grade. Textbook set analysis is based on four holistic SMRs descriptors (direct, indirect, combined descriptor, and SMRs without descriptors), which support learners' recognition of SMRs' informational value at different levels by providing different accompanying SMRs add-ons. The textbook sets analysis revealed that the number of SMRs varies significantly with regard to different curriculum topics. The overall proportion of the descriptors that enable the learner a direct recognition of SMRs is low in all curriculum topics. Interestingly, the descriptors that do not enable the learners a direct recognition of SMRs prevail in textbook sets. To obtain more detailed insight into the criteria based on which the textbook authors integrate SMRs with various descriptors into textbook sets, further studies are necessary.
\end{abstract}

Keywords: Chemistry, curriculum, submicroscopic representations, textbook

\section{Introduction}

Textbooks are an important resource in supporting the effective teaching and learning of chemistry, as one school subject in the larger field of science education. They can be used for studying at school as well as at home. ${ }^{1}$ In order to be used as teaching materials at schools, the textbook sets for chemistry should be synchronised with the National Curriculum for Chemistry at certain educational levels ${ }^{2,3}$ and confirmed by the National Commission for Textbook Approval at the Ministry of Education of the Republic of Slovenia. ${ }^{4}$ To support the quality of the textbook sets in chemistry education, significant attention has been paid to textbook analysis. For example, Abraham et al. ${ }^{5}$ studied eighth graders' degree of understanding of five selected chemistry concepts found in textbooks and attempted to identify related misconceptions; Sanger and Greenbowe ${ }^{6}$ analysed the college chemistry textbooks as sources of misconceptions and errors in electrochemistry; Abd-El-Khalick, Waters, and $\mathrm{Le}^{7}$ studied representations of nature of science in high school chemistry textbooks over the past four decades; Devetak, Vogrinc, and Glažar ${ }^{8}$ studied explanations of states of matter in Slovenian science textbooks from 1 th to 8th Grade; and Souza and Porto 9 analysed iconographic and textual aspects of chemistry textbooks which had significant diffusion in the context of Brazilian universities.

Johnstone $^{10}$ suggested that representing chemistry concepts and processes is based on representations at three levels: macroscopic (observable phenomena), submicroscopic or particulate (different representations of atomic, molecular, and particle structures), and symbolic (mathematical and chemical symbols). The understanding of chemistry is based on creating mental images for corresponding phenomena on the particulate level. Such mental images are considered to be internal representations that can be visualised through the use of special symbolic systems, so-called external representations of the particulate nature of matter, ${ }^{11,12}$ which are referred to as submicroscopic representations (SMRs) in this paper. Few macroscopic observations can be understood without recourse to sub-microscopic representation or models. ${ }^{13}$ Various visualisations are used to support students when connecting the three levels of concept representations, ${ }^{14-16}$ as the interpretation of the macroscopic phenomenon at the particulate level is perceived to be an important part in contemporary chemistry teaching. ${ }^{17}$ 


\section{The Context and the Purpose of the Study}

This paper focuses on SMRs in Slovenian chemistry textbook sets with respect to the topics of the National Chemistry Curriculum for 8th and 9th Grade. ${ }^{3}$ Previous research has been dealing with misconceptions related with SMRs. ${ }^{18}$ The novelty of the present research is in focusing on the descriptors, which accompanying SMRs. Namely, based on their own acceptance of the simultaneous use of SMRs as a part of a triple representation of chemistry concepts (submicroscopic, macroscopic and symbolic levels), chemistry educators, such as authors of textbooks, can assume that students can also easily comprehend and efficiently learn with the use of SMRs. ${ }^{10}$ However, the understanding of the kinds of information and inferences that the visualisations in various learning materials provide requires explicit instruction and practice. ${ }^{19}$ The research indicates that students' successful learning with SMRs is significantly impacted by their representational competence in chemistry. ${ }^{20-22}$ The representational competence includes a distinct set of skills for constructing, selecting, interpreting, and using disciplinary representations for communicating, learning, or problem solving. ${ }^{23}$ Moreover, in the textbook sets the authors can unintentionally devote more emphasis to the implementation of SMRs in particular topics, whereas in others the particulate representations can be neglected.

The following research questions (RQ) were stated:

$1^{\text {st }}$ RQ: How does the number of SMRs in Slovenian chemistry textbook sets for 8th and 9th Grade change with respect to curriculum topics?

$2^{\text {nd }}$ RQ: What holistic descriptors of SMR add-ons are used to support learners in the recognition of SMRs' informational value in specific curriculum topics of Slovenian chemistry textbook sets for 8 th and 9th Grade?

$3^{\text {rd }}$ RQ: How does the number of specific holistic descriptors of SMR add-ons in Slovenian chemistry textbook sets for 8th and 9th Grade change with respect to curriculum topics?

Table 1. The list of the analysed textbook sets

\begin{tabular}{|c|c|c|c|c|c|}
\hline $\begin{array}{l}\text { Textbook set } \\
\text { title }\end{array}$ & Author(s) & Publisher & $\begin{array}{c}\begin{array}{c}\text { Year of } \\
\text { publication } \\
\text { (Edition) }\end{array} \\
\text { Textbook/ } \\
\text { workbook }\end{array}$ & $\begin{array}{c}\begin{array}{c}\text { Number } \\
\text { of Pages }\end{array} \\
\text { Textbook/ } \\
\text { workbook }\end{array}$ & $\begin{array}{c}\text { Grade/ } \\
\text { Learner's } \\
\text { age }\end{array}$ \\
\hline Kemija danes 1 & $\begin{array}{l}\text { Gabrič, A., Glažar, S. A., Graunar, } \\
\text { M., Slatinek-Žigon, M. }\end{array}$ & DZS & $\begin{array}{l}2014\left(1^{\text {st }} \mathrm{Ed} .\right) / \\
2013\left(1^{\text {st }} \mathrm{Ed} .\right)\end{array}$ & $125 / 106$ & $8 / 13$ \\
\hline $\begin{array}{l}\text { Kemija 8, } \\
\text { i-učbenik }\end{array}$ & $\begin{array}{l}\text { Sajovic, I., Wissiak Grm, K., Godec, A., } \\
\text { Kralj, B., Smrdu, A., Vrtačnik, M., Glažar, S. }\end{array}$ & $\begin{array}{l}\text { Zavod RS } \\
\text { za šolstvo }\end{array}$ & 2014 & 264 & $8 / 13$ \\
\hline $\begin{array}{l}\text { Moja prva } \\
\text { kemija }\end{array}$ & $\begin{array}{l}\text { Vrtačnik, M., Wissiak Grm, K. S., } \\
\text { Glažar, S. A., Godec, A. }\end{array}$ & Modrijan & $\begin{array}{l}2015\left(1^{\text {st }} \mathrm{Ed} .\right) / \\
2014\left(1^{\text {st }} \mathrm{Ed} .\right)\end{array}$ & $\begin{array}{l}240 / 92 \\
61\end{array}$ & $\begin{array}{l}8,9 / 13 \\
14\end{array}$ \\
\hline Peti element 8 & Devetak, I., Cvirn Pavlin, T., Jamšek, S. & $\begin{array}{l}\text { ROKUS } \\
\text { KLETT }\end{array}$ & $\begin{array}{l}2010\left(1^{\text {st }} \mathrm{Ed} .\right) / \\
2010\left(1^{\text {st }} \mathrm{Ed} .\right)\end{array}$ & $103 / 71$ & $8 / 13$ \\
\hline $\begin{array}{l}\text { Pogled } \\
\text { v kemijo } 8\end{array}$ & Kornhauser, A., Frazer, M. & MK & $\begin{array}{l}2003\left(1^{\text {st }} \mathrm{Ed} .\right) / \\
2004\left(1^{\text {st }} \mathrm{Ed} .\right)\end{array}$ & $140 / 126$ & $8 / 13$ \\
\hline $\begin{array}{l}\text { Od atoma } \\
\text { do molekule }\end{array}$ & Smrdu, A. & JUTRO & $\begin{array}{l}2012\left(2^{\text {nd }} E d .\right) / \\
2012\left(2^{\text {nd }} E d .\right)\end{array}$ & $128 / 160$ & $8 / 13$ \\
\hline $\begin{array}{l}\text { Kemija } \\
\text { danes } 2\end{array}$ & $\begin{array}{l}\text { Graunar, M., Podlipnik, M., Mirnik, J. (textbook) } \\
\text { Dolenc, D., Graunar, M., Modec, B. (notebook) }\end{array}$ & DZS & $\begin{array}{l}2016\left(1^{\text {st }} \mathrm{Ed} .\right) / \\
2016\left(1^{\text {st }} \mathrm{Ed} .\right)\end{array}$ & $152 / 96$ & $9 / 14$ \\
\hline $\begin{array}{l}\text { Kemija 9, } \\
\text { i-učbenik }\end{array}$ & $\begin{array}{l}\text { Jamšek, S., Sajovic, I., Wissiak Grm, K., } \\
\text { Godec, A., Boh, B., Vrtačnik, M., Glažar, S. }\end{array}$ & $\begin{array}{l}\text { Zavod RS } \\
\text { za šolstvo }\end{array}$ & 2014 & 271 & $9 / 14$ \\
\hline Peti element 9 & Devetak, I., Cvirn Pavlin, T., Jamšek, S. & $\begin{array}{l}\text { ROKUS } \\
\text { Klett }\end{array}$ & $\begin{array}{l}2011\left(1^{\text {st }} \mathrm{Ed} .\right) / \\
2011\left(1^{\text {st }} \mathrm{Ed} .\right)\end{array}$ & $77 / 79$ & $9 / 14$ \\
\hline Pogled v kemijo 9 & Kornhauser, A., Frazer, M. & MK & $\begin{array}{l}2005\left(1^{\text {st }} \mathrm{Ed} .\right) / \\
2006\left(1^{\text {st }} \mathrm{Ed} .\right)\end{array}$ & $140 / 115$ & $9 / 14$ \\
\hline $\begin{array}{l}\text { Od molekule do } \\
\text { makromolekule }\end{array}$ & Smrdu, A. & Jutro & $\begin{array}{l}2013\left(2^{\text {nd }} E d .\right) / \\
2013\left(2^{\text {nd }} E d .\right)\end{array}$ & $128 / 152$ & $9 / 14$ \\
\hline
\end{tabular}

The term "textbook set $\left({ }^{*}\right)$ " refers to all materials for students in the written or electronic form. 


\section{Methods}

\section{1. Sample}

In this study, we focused on the chemistry textbook sets in primary school (8th and 9th Grade), which are in Slovenia obligatory written based on the objectives of National Chemistry Curriculum and consequently confirmed by the National Commission for Textbook Approval at the Ministry of Education, Science and Sport in the 2016/17 school year. National Chemistry Curriculum for 8th and 9th Grade ${ }^{3}$ for each of the ten topics (Chemistry is a World of Matter, Atom and the Periodic System of Elements,
Compounds and Bonding, Chemical Reactions, The Elements in the Periodic Table, Acids, Bases and Salts, Hydrocarbons and Polymers, Organic Compounds Containing Oxygen, Organic Compounds Containing Nitrogen, The Mole) specifies specific objectives and points out suggested contents how to implement them in chemistry teaching. Teachers are free to distributed the above listed curriculum topics in 70 hours in Grade 8 and 64 hours in Grade 9 with regard to their opinion.

A list of analysed textbook sets is shown in Table 1. As can be derived from the Table 1, in the present study 2826 pages were analysed.

Table 2. Examples of SMR add-ons

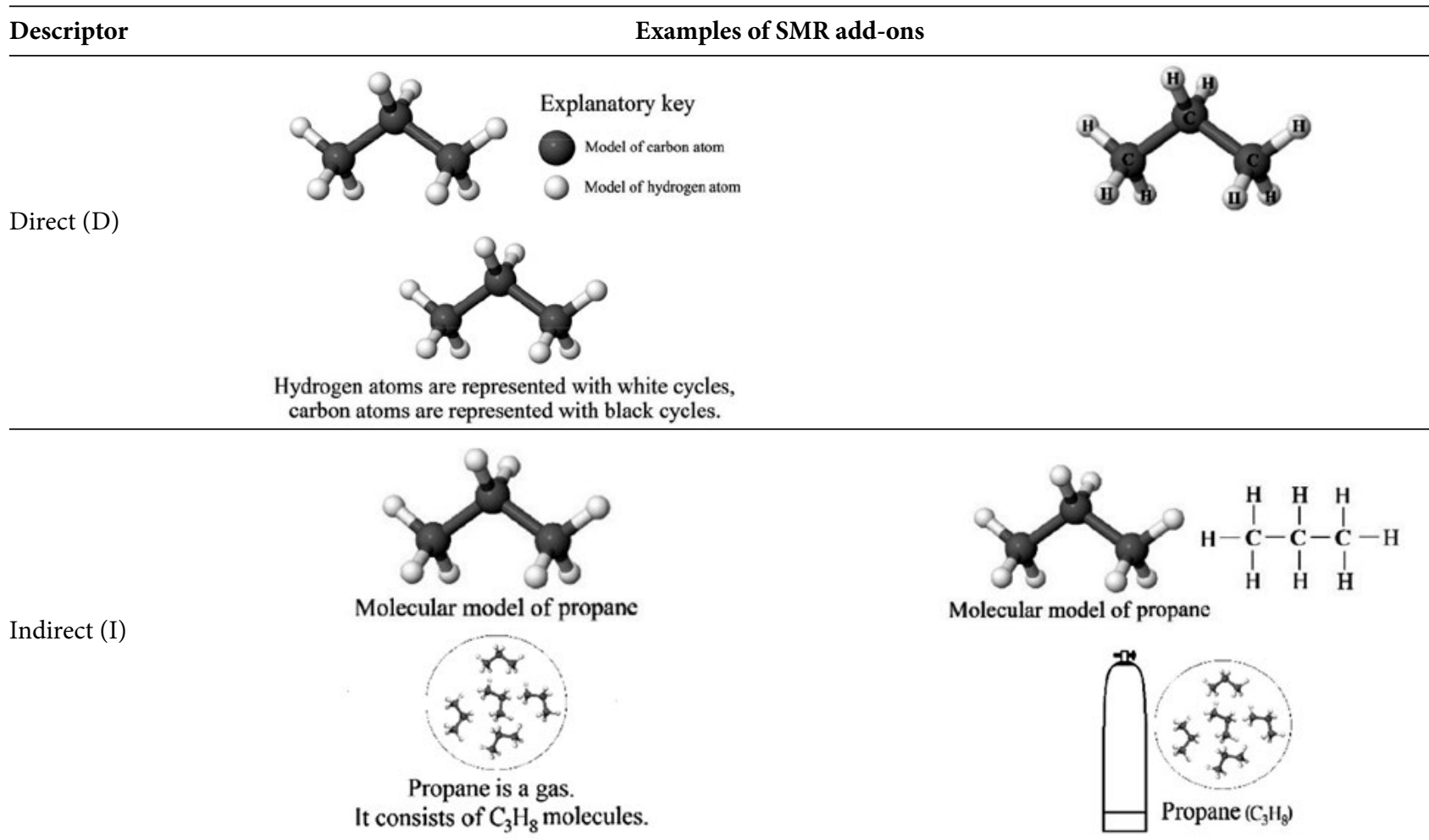

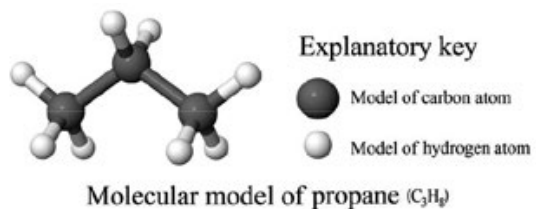

Combined (C)

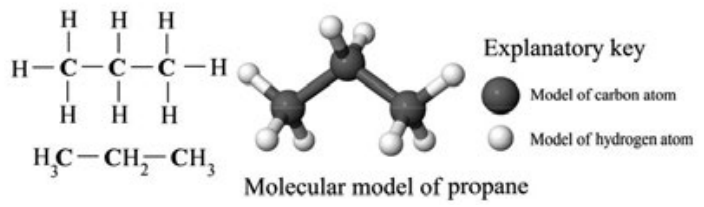

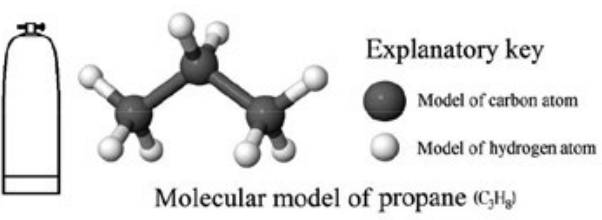

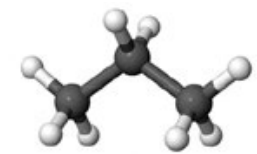

Molecular model of propane

Hydrogen atoms are represented with white cycles, carbon atoms are represented with black cycles.

Without (W)

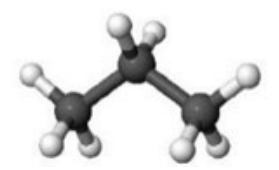




\section{2. Instruments}

For the purpose of this research, a rubric ${ }^{24}$ for the evaluation of SMRs in the textbook sets was used. This rubric was based on the assumption that in practice the learner perceives each SMR as one whole. The four main holistic descriptors accompanying SMRs were used: i.e. direct descriptor (D), indirect descriptor (I), combined descriptor (C), and SMRs without descriptors (W), which support learners' recognition of SMRs' informational value on different levels by providing different accompanying add-ons of SMRs. To ensure the validity of the rubric, 283 pages ( $10 \%$ of all analysed textbook set pages) were analysed by both authors, and the four main types of holistic descriptors were defined. To reduce bias issues related to the use of the rubric for categorisation of SMR descriptors, through discussion and agreement, a 95\% inter-rater reliability of the rubric was established. The direct SMR add-ons enable the learner a direct and unambiguous recognition of particles. Thereby, various types of explanatory keys can be used: for example, pictorial, textual, integrated structural, or other symbolic notations used in the explanatory key. Indirect SMR add-ons do not enable the learner a direct recognition of particles. The nature of the particles can be derived based on the compound's name, structure-properties relation or symbolic SMR add-ons, or by other means, but only in cases that the learners have the necessary chemical knowledge, that enables the recognition of its informational value. Combined SMR add-ons enable the learner a direct recognition and provide other information. It is a combination of the direct and the indirect descriptor. Examples of SMR add-ons are presented in Table 2. In order to visualize descriptors explicitly, the type of descriptors represents the only variable and SMR add-ons are accompanying SMR of the same compound (propane molecule).

\section{3. Data analysis}

The rubric described in the instrument section was used in the analysis of the chemical representations of the entire sample of chemistry textbook sets, which are presented in Table 1. The textbook sets were analysed individually. The SMRs were categorised with regard to curriculum topics of the National Chemistry Curriculum for 8th and 9th Grade. ${ }^{3}$ The core topics in which SMRs were categorised are the following: (1) Chemistry is a World of Matter (orig. Kemija je svet snovi); (2) Atom and the Periodic System of Elements (orig. Atom in periodni sistem elementov); (3) Compounds and Bonding (orig. Povezovanje delcev/gradnikov); (4) Chemical Reactions (orig. Kemijske reakcije); (5) The Elements in the Periodic Table (orig. Elementi v periodnem sistemu); (6) Acids, Bases and Salts (orig. Kisline, baze in soli); (7) Hydrocarbons and Polymers (orig. Družina ogljikovodikov s polimeri); (8) Organic Compounds Containing Oxygen (orig. Kisikova družina organskih snovi); (9) Organic Compounds Containing Nitrogen (orig. Dušikova družina organskih spojin) and (10) The Mole (orig. Množina snovi). Eventually, the number of SMRs in each of the topics were counted and the frequencies calculated. Analysed SMRs involved SMRs of molecules, atoms and ions.

\section{Results and Discussion}

The results of the analysis are presented with regard to the research questions.

\section{1. The Number of SMRs in Slovenian Chemistry Textbook Sets for 8th and 9th Grade Change With Respect to Curriculum Topics (Related to RQ1)}

The number of images about the SMRs in chemistry textbook sets is given in Table 3. Most frequently, the SMRs were used in the topics "Hydrocarbons and Polymers" (28.68\%; 407 SMRs) and "Organic Compounds Containing Oxygen" (20.23\%; 287 SMRs). The lowest frequencies of the use of SMRs were found in the following

Table 3. The proportion of SMRs and curriculum objectives in the particular topics of the textbook sets

\begin{tabular}{|c|c|c|c|c|}
\hline \multirow{2}{*}{$\begin{array}{l}\text { The topics of the National Chemistry Curriculum } \\
\text { for } 8^{\text {th }} \text { and } 9^{\text {th }} \text { Grade }\end{array}$} & \multicolumn{2}{|c|}{ SMRs } & \multicolumn{2}{|c|}{$\begin{array}{c}\text { Curriculum } \\
\text { objectives }\end{array}$} \\
\hline & $\mathbf{N}$ & $f(\%)$ & $\mathbf{N}$ & $\mathbf{f}(\%)$ \\
\hline Chemistry is a World of Matter (1) & 179 & 12.61 & 5 & 8.62 \\
\hline Atom and the Periodic System of Elements (2) & 29 & 2.04 & 4 & 6.90 \\
\hline Compounds and Bonding (3) & 150 & 10.57 & 5 & 8.62 \\
\hline Chemical Reactions (4) & 69 & 4.86 & 6 & 10.34 \\
\hline The Elements in the Periodic Table (5) & 16 & 1.13 & 7 & 12.07 \\
\hline Acids, Bases and Salts (6) & 160 & 11.28 & 7 & 12.07 \\
\hline Hydrocarbons and Polymers (7) & 407 & 28.68 & 9 & 15.52 \\
\hline Organic Compounds Containing Oxygen (8) & 287 & 20.23 & 7 & 12.07 \\
\hline Organic Compounds Containing Nitrogen (9) & 116 & 8.17 & 5 & 8.62 \\
\hline The Mole (10) & 6 & 0.42 & 3 & 5.17 \\
\hline SUM & 1419 & 100.00 & 58 & 100.00 \\
\hline
\end{tabular}


topics: The Mole $(0.42 \%$; 6 SMRs), The Elements in the Periodic Table (1.13\%; 16 SMRs) and Atom and the Periodic System of Elements (2.04\%; 29 SMRs).

It was expected that the change in the number of the SMRs would be proportionally related to the number of objectives in the specific chemistry topics, as the objectives in the Chemistry Curriculum for $8^{\text {th }}$ and $9^{\text {th }}$ Grade $^{3}$ are written operationally and can be interpreted by the use of representations on all three representational levels (macroscopic, submicroscopic, and symbolic). This has been proven true for the topics in which the highest proportion of the SMRs has been used. The highest proportion of SMRs in the chemistry textbook sets for the curriculum topic "Hydrocarbons and Polymers" (28.68\%; 407 SMRs) is proportional to the highest proportion of objectives in this topic (15.52\%; 9 objectives). Similarly, the proportion of SMRs in the chemistry textbook sets for the curriculum topic "Organic Compounds Containing Oxygen" (20.23\%; 287 SMRs) are proportional to the proportion of objectives in this topic (12.07\%; 7 objectives). Chemistry concepts and processes of these topics are traditionally explained by combining all three representational levels, which is also encouraged with the notations of the curriculum objectives that directly indicate the relationship between structure, properties, and application of substances. For example, one of the objectives in the curriculum topic "Hydrocarbons and Polymers" states: "Students should know that carbon and hydrogen are the fundamental elements of organic compounds - hydrocarbons, and they can identify the causes for the abundance and the variety of organic compounds". ${ }^{24}$

Despite the high proportion of associated objectives (10.34\%; 6 objectives) in the curriculum, the textbook set analysis revealed surprisingly a low number of SMRs used in the curriculum topic "Chemical Reactions" (4.86\%; 69 SMRs). Furthermore, the manner in which notations of the objectives are written indicates the need for their explanation by the combined use of the three levels of their representation. For example, it would be expected that for the achievement of the objectives such as "Students should be able to define reactants and products of chemical reactions" ${ }^{26}$ and "Students should get acquainted with chemical equations as notations of chemical reactions" 26 would be to a greater proportion presented in the textbooks, not only with photos of the phenomena and/or examples of experiments with their symbolic notations but also with the underlying SMRs.

More frequent use of the triple-nature representations of chemistry concepts would also be expected in the curriculum topic "The Elements in the Periodic Table". However, as mentioned before, the number of SMRs in this topic are one of the lowest among the curriculum topics (Table 3). One of the reasons for the lower proportions of SMRs could also be in the nature of some of the objectives. In particular, some objectives explicitly refer to the macroscopic representational level, e.g. "Students should get to know natural resources of elements and compounds" ${ }^{27}$ or to the development of stoichiometric skills, e.g. "Students should know how to calculate a mass percentage of the elements in the compounds". ${ }^{27}$ Consequently, in these cases the use of SMRs could easily be neglected.

\section{2. Holistic descriptors of SMR add-ons used to support learners in the recognition of SMRs' informational value in specific curriculum topics of Slovenian chemistry textbook sets for $8^{\text {th }}$ and $9^{\text {th }}$ Grade (related to RQ2)}

The analysis revealed that various topics of the Chemistry Curriculum for $8^{\text {th }}$ and $9^{\text {th }}$ Grade ${ }^{3}$ include not only different numbers of SMRs but that those SMRs also include different add-ons. The descriptors of the SMR addons have already been presented in Table 2. As expected, the analysis of the textbooks revealed that the authors of the textbook sets used various proportions of different types of descriptors of SMR add-ons in specific topics, which is presented in Table 4 and Table 5.

In the top three topics in which SMRs are most frequently used, i.e. "Hydrocarbons and Polymers", "Organic Compounds Containing Oxygen" and "Chemistry is a World of Matter", the use of indirect SMRs add-ons prevail (56.27\%, 229 SMRs; 69.69\%, 200 SMRs; 36.87\%, 66 SMRs, respectively). However, it is interesting that more than one third of SMRs (35.87\%, 146 SMRs; 26.13, 75 SMRs; 35.20\%, 63 SMRs, respectively) do not include any descriptors. In these cases, the recognition of the informational value of particular SMRs depends entirely on learners' previous experience, knowledge, and their representational competence. This is surprising for the first curriculum topic "Chemistry is a World of Matter", as it should introduce some of the examples of simple compounds and the states of matter on the particle level, where students' development of their representational competence needs to be systematically supported by explicit instruction and practice. ${ }^{18}$ In "Hydrocarbons and Polymers" and "Organic Compounds Containing Oxygen" other types of SMR descriptors occur rarely, but in the first topic of the curriculum "Chemistry is a World of Matter", in addition to the indirect descriptor of SMR add-ons also the significant proportion of the combined descriptors $(26.26 \% ; 47$ SMRs) were found. In these cases, the recognition of the informational value of a particular SMR is supported by SMR add-ons and the learners' previous experience, knowledge, and their representational competence.

As mentioned earlier, in the topics of the curriculum "Atom and the Periodic System of Elements", "The Elements in the Periodic Table", and "The Mole", the lowest frequencies of the use of SMRs were found. However, the analysis of different types of SMRs add-ons in the second curriculum topic "Atom and the Periodic System of Ele- 
ments" reveals that more than half of the SMRs cases are accompanied by indirect descriptors (55.17\%; 16 SMRs) of SMR add-ons, more than one third of SMRs enable the learner a direct recognition of particles (10.34\%; 3 SMRs) and provide other information - combined descriptor (31.03\%; 9 SMRs). In this case the recognition of the informational value of a particular SMR is substantially supported by SMR add-ons, which greatly enables students easier understanding of the atomic structure, ions formation from the atoms and, consequently, the understanding of the relation between atomic structure and their position in the Periodic Table of Elements with regard to the objectives of the curriculum. ${ }^{3}$ In the fifth topic of the curriculum, "The Elements in the Periodic Table", the SMR cases with indirect descriptors of SMR add-ons (62.50\%; 10 SMRs) prevail. The second most frequently used SMRs are SMRs without SMR add-ons (25.00\%; 4 SMRs). In the last curriculum topic "The Mole" two thirds of SMRs do not have SMRs add-ons (66.67\%; 4 SMRs) and the rest have an indirect descriptor (33.33\%; 2 SMRs). For the recognition of SMRs' informational value learners need to rely on their previous experience, knowledge, and representational competence developed in earlier topics of the curriculum.

In all of the remaining topics "Acids, Bases and Salts", "Compounds and Bonding", "Organic Compounds Containing Nitrogen" and "Chemical reactions" the indirect
SMR add-ons prevail (45.63\%, 73 SMRs; 58.67\%, 88 SMRs; $56.03 \%$, 65 SMRs; 59.42\%, 41 SMRs, respectively). Moreover, in these topics, which are placed in different parts of the curriculum, a high proportion of SMRs without any SMR add-ons was found, which do not support recognition of SMRs' informational value.

\section{3. Holistic descriptors of SMR add-ons used to support learners in the recognition of SMRs' informational value in particular curriculum topics of Slovenian chemistry textbook sets for $8^{\text {th }}$ and $9^{\text {th }}$ Grade (related to $\mathrm{RQ3})$}

In the textbook set analysis, particular attention has been devoted to studying whether the authors systematically planned the integration of SMS in the textbooks in order to support students' development of their representational competence. Specifically, in order to do so, Hinze, Rapp, Williamson, et al., ${ }^{19}$ pointed out that explicit instruction for that purpose and practice with the use of particular representations, e.g. SMRs, is necessary. In the context of the textbook sets, it would mean, that particular kinds of SMRs with add-ons would be carefully selected and their integration into the textbook sets continuously upgraded throughout the curriculum.

Table 4. The proportion of SMRs within the particular topics of the textbook sets - part 1

\begin{tabular}{|c|c|c|c|c|c|c|c|c|c|c|c|c|}
\hline \multirow{3}{*}{$\begin{array}{l}\text { Descriptor } \\
\text { of SMR } \\
\text { add-ons }\end{array}$} & \multicolumn{12}{|c|}{ The first five topics of the National Chemistry Curriculum for $8^{\text {th }}$ and $9^{\text {th }}$ Grade $^{3}$} \\
\hline & \multicolumn{2}{|c|}{ General } & \multicolumn{2}{|c|}{$\begin{array}{l}\text { Chemistry is } \\
\text { a World of } \\
\text { Matter }\end{array}$} & \multicolumn{2}{|c|}{$\begin{array}{l}\text { Atom and the } \\
\text { Periodic } \\
\text { System of } \\
\text { Elements }\end{array}$} & \multicolumn{2}{|c|}{$\begin{array}{l}\text { Compounds } \\
\text { and Bonding }\end{array}$} & \multicolumn{2}{|c|}{$\begin{array}{l}\text { Chemical } \\
\text { Reactions }\end{array}$} & \multicolumn{2}{|c|}{$\begin{array}{c}\text { The Elements } \\
\text { in the } \\
\text { Periodic } \\
\text { in Table }\end{array}$} \\
\hline & $\mathbf{N}$ & $\mathrm{f}(\%)$ & $\mathbf{N}$ & fc $(\%)$ & $\mathbf{N}$ & $\mathrm{fc}(\%)$ & $\mathbf{N}$ & fc $(\%)$ & $\mathbf{N}$ & fc $(\%)$ & $\mathbf{N}$ & fc $(\%)$ \\
\hline Direct (D) & 63 & 4.44 & 3 & 1.68 & 3 & 10.34 & 5 & 3.33 & 16 & 23.19 & 2 & 12.50 \\
\hline Indirect (I) & 790 & 55.67 & 66 & 36.87 & 16 & 55.17 & 88 & 58.67 & 41 & 59.42 & 10 & 62.50 \\
\hline Combined (C) & 147 & 10.36 & 47 & 26.26 & 9 & 31.03 & 26 & 17.33 & 6 & 8.70 & 0 & 0.00 \\
\hline Without (W) & 419 & 29.53 & 63 & 35.20 & 1 & 3.45 & 31 & 20.67 & 6 & 8.70 & 4 & 25.00 \\
\hline SUM & 1419 & 100.00 & 179 & 100.00 & 29 & 100.00 & 150 & 100.00 & 69 & 100.00 & 16 & 100.00 \\
\hline
\end{tabular}

Table 5. The proportion of SMRs within the particular topics of the textbook sets - part 2

\begin{tabular}{|c|c|c|c|c|c|c|c|c|c|c|}
\hline \multirow{3}{*}{$\begin{array}{l}\text { Descriptor of } \\
\text { SMR add-ons }\end{array}$} & \multicolumn{10}{|c|}{ The last five topics of the National Chemistry Curriculum for $8^{\text {th }}$ and $9^{\text {th }}$ Grade ${ }^{3}$} \\
\hline & \multicolumn{2}{|c|}{$\begin{array}{c}\text { Acids, Bases } \\
\text { and Salts }\end{array}$} & \multicolumn{2}{|c|}{$\begin{array}{l}\text { Hydrocarbons } \\
\text { and Polymers }\end{array}$} & \multicolumn{2}{|c|}{$\begin{array}{c}\text { Organic } \\
\text { Compounds } \\
\text { Containing } \\
\text { Oxygen }\end{array}$} & \multicolumn{2}{|c|}{$\begin{array}{c}\text { Organic } \\
\text { Compounds } \\
\text { Contenting } \\
\text { Nitrogen }\end{array}$} & \multicolumn{2}{|c|}{ The Mole } \\
\hline & $\mathbf{N}$ & fc $(\%)$ & $\mathbf{N}$ & fc $(\%)$ & $\mathbf{N}$ & $\mathrm{fc}(\%)$ & $\mathbf{N}$ & $\mathrm{fc}(\%)$ & $\mathbf{N}$ & fc $(\%)$ \\
\hline Direct (D) & 11 & 6.88 & 17 & 4.18 & 6 & 2.09 & 0 & 0.00 & 0 & 0.00 \\
\hline Indirect (I) & 73 & 45.63 & 229 & 56.27 & 200 & 69.69 & 65 & 56.03 & 2 & 33.33 \\
\hline Combined (C) & 38 & 23.75 & 15 & 3.69 & 6 & 2.09 & 0 & 0.00 & 0 & 0.00 \\
\hline Without (W) & 38 & 23.75 & 146 & 35.87 & 75 & 26.13 & 51 & 43.97 & 4 & 66.67 \\
\hline SUM & 160 & 100.00 & 407 & 100.00 & 287 & 100.00 & 116 & 100.00 & 6 & 100.00 \\
\hline
\end{tabular}




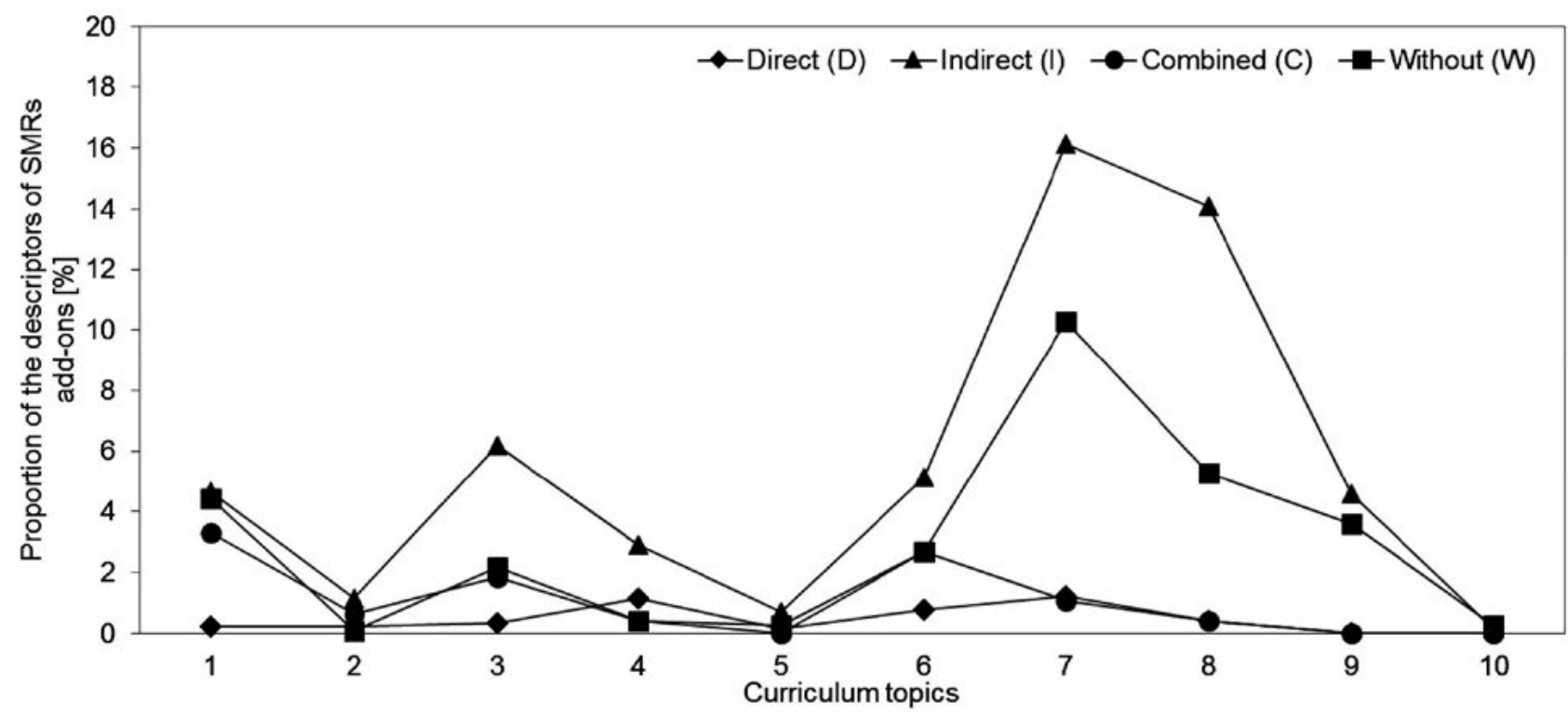

Figure 1. The proportion of SMRs with particular descriptors within all of the topics in the textbook sets [Curriculum topics: Chemistry is a World of Matter (1); Atom and the Periodic System of Elements (2); Compounds and Bonding (3); Chemical Reactions (4); The Elements in the Periodic Table (5); Acids, Bases and Salts (6); Hydrocarbons and Polymers (7); Organic Compounds Containing Oxygen (8); Organic Compounds Containing Nitrogen (9); The Mole (10)]

From Figure 1, it can be seen how the overall proportion of different descriptors of SMR add-ons are distributed through the topics of the curriculum. The textbook set analysis revealed that the overall proportion of direct and combined descriptors of SMR add-ons is significantly low through all the curriculum topics (range from $0.00 \%$ to $3.31 \%$ ). That can be connected with the Johnstone's claim ${ }^{10}$ that the experienced chemists do the transition between levels of representations very easily and they assumed that learners can do this as easily as they do. These simplified assumptions about learners' easy comprehension and efficient learning with SMRs are reflecting in the low frequency of SMR descriptors, where the informational value of a particular SMR enables the learner a direct recognition of particles, in textbook sets.

It can also be observed from Figure 1, that the overall percentages of SMRs with indirect descriptors or without any add-ons throughout the curriculum are higher than the percentages of SMRs with direct and combined descriptors of SMR add-ons, whereby the figures in the topics "Hydrocarbons and Polymers" and "Organic Compounds Containing Oxygen" stand out (range from 5.29\% to $16.14 \%)$. From the perspective of the integration of SMRs into the textbook sets based on the assumption about their continuous upgrading throughout the curriculum topics (from the first to last topic), this is a very interesting finding. It can be related to the fact that in these chapters the highest proportion of SMSs is used from all curriculum topics, as proposed earlier, probably as a consequence of the number of curriculum objectives for these topics (Table 3). However, the ratio among the different descriptors of SMR add-ons used in these chapters speaks in favour of indirect SMR add-ons, which do not enable the learner a direct recognition of particles, as well as SMRs without add-ons, which do not provide any additional information to support the learner's recognition process. The reason for the use of such representations at that point of the textbook sets could either be that the authors assume that the learners are already able to recognise the informational value of SMRs indirectly, because their representational competence has been adequately developed in previous topics, or that the authors integrate SMRs with add-ons into the textbook sets without considering how the correct recognition of the informational value by learners might affect the learning process based on it.

As only a low proportion of direct and combined SMR add-ons was found in the textbook set analysis, it seems worthy to encourage textbook authors to devote special attention to optimally equip the SMRs with addons to support students' development of the representational competence across the curriculum. When the learners' perception of SMRs is not a possible initial obstacle for learning, it will be easier to overcome the range of students' misconceptions, related to particle nature of chemical concepts, i.e. in making the distinctions between elements, compounds, and mixtures; appreciations of the reversibility of state changes; seeing atoms and ions as the building blocks of matter; appropriate use of basic chemistry terminology, understanding that Broensted acids and bases are not substances but molecules and ions etc. ${ }^{28-31}$ On the other hand it is important to pay attention to scientific accuracy of SMRs to enable appropriate understanding of chemical concepts and processes. 


\section{Conclusions}

When learning chemistry, learners are often challenged by various representations at the submicroscopic level that are included in learning materials, such as textbook sets, to develop understanding of chemistry concepts and processes at the particulate level. Previous research ${ }^{19,23}$ has demonstrated that the understanding of visualisations in various learning materials based on recognising the informational value of various representations requires explicit instruction and practice.

This paper presents an analysis of the chemistry textbook sets for 8th and 9th Grade in Slovenia from the perspective of the integration of SMRs into various National Chemistry Curriculum ${ }^{3}$ topics. In particular, it was found that the number of SMRs in Slovenian chemistry textbook sets varies significantly with regard to different curriculum topics. In the topics where the highest proportion of the SMRs has been used ("Hydrocarbons and Polymers", "Organic Compounds Containing Oxygen"), the number of the SMRs is proportionally related to the number of objectives in the specific chemistry topics. Despite the high proportion of objectives in the curriculum, the textbook sets analysis indicates a surprisingly low number of the SMRs used in the curriculum topics "Chemical Reactions" and "The Elements in the Periodic Table".

Regarding the holistic descriptors of SMR add-ons, that are used to support learners in the recognition of SMRs' informational value in various curriculum topics, it was found that the descriptors that do not enable the learners a direct recognition of SMRs prevail, especially in the topics "Hydrocarbons and Polymers" and "Organic Compounds Containing Oxygen", which are in the final part of the curriculum.

In contrast, the textbook set analysis revealed that the overall proportion of the descriptors that enable the learner a direct recognition of the informational value of SMRs is very low through all the curriculum topics. The results can serve as a foundation for a discussion with textbook authors about the role of SMRs with add-ons in supporting students' development of representational competence across curriculum as well as in the learning process, as it seems valuable that the particular kinds of SMRs with add-ons would be carefully selected and their integration into the textbook sets continuously upgraded throughout the curriculum. Further studies are necessary to obtain more detailed insight into the criteria based on which the authors integrate SMRs with various descriptors into textbook sets.

From the learner's point of view, in future studies, it would be valuable to focus on research possibilities provided by contemporary technology, such as Eyetracker, for following the learner's information processing and their use of SMRs in learning with traditional as well as with e-learning materials. Thus far, for example, the importance of various features and notations of visualisations for the learners has been examined with eye trackers by William- son et al., ${ }^{32}$ who studied students' use of ball-and-stick images versus electrostatic potential maps when considering electron density, positive charge, proton attack, and hydroxide attack; O'Keefe et al., ${ }^{33}$ who examined how the integration of multiple representations was associated with learning in a multimedia simulation; Ferk Savec et al. ${ }^{34}$ examined some of the features of the explanatory key, such as coloured versus black-and-white explanatory keys, and pictorial versus textual explanatory keys, etc.

The results of such studies contribute to the quality of the textbook sets and consequently also to the quality of chemistry teaching and learning, as they can be used for studying in various learning environments.

\section{References}

1. V. Gkitzia, K. Salta, C. Tzougraki, Chem. Educ. Res. Pract. 2011, 12, 5-14. DOI:10.1039/C1RP90003J

2. A. Bačnik, N. Bukovec, A. Poberžnik, T. Požek Novak, Z. Keuc, H. Popič, M. Vrtačnik, in: N. Purkat (Ed.): Učni načrt. Program gimnazija. Kemija, Ministrstvo za šolstvo in šport, Zavod RS za šolstvo, Ljubljana, 2008, 59 pp.

3. A. Bačnik, N. Bukovec, M. Vrtačnik, A. Poberžnik, M. Križaj, V. Stefanovik, K. Sotlar, S. Dražumerič, S. Preskar, in: A. Štrukelj (Ed.): Učni načrt. Program osnovna šola. Kemija, Ministrstvo za šolstvo in šport, Zavod RS za šolstvo, Ljubljana, 2011, $31 \mathrm{pp}$.

4. Ministrstvo za izobraževanje, znanost in šport, Trubar učbeniški sklad, https://soca1.mss.edus.si/Trubar/default.aspx, (assessed: June 9, 2017)

5. M. R. Abraham, E. B. Grzybowski, J. W. Renner, E. A. Marek, J. Res. Sci. Teach. 1992, 29, 105-120.

DOI:10.1002/tea.3660290203

6. M. J. Sanger, T. J. Greenbowe, J. Chem. Educ. 1999, 76, 853860. DOI:10.1021/ed076p853

7. F. Abd-El-Khalick, M. Waters, A. P. Le, J. Res. Sci. Teach. 2008, 45, 835-855. DOI:10.1002/tea.20226

8. I. Devetak, J. Vogrinc, S. A. Glažar, Int. J. Env. Sci. Ed. 2010, 5, 217-235.

9. K. A. F. Souza, P. A. Porto, Sci. Educ. 2012, 21, 705-727. DOI:10.1007/s11191-012-9442-z

10. A. H. Johnstone, J. Comput. Assist. Learn. 1991, 7, 75-83. DOI:10.1111/j.1365-2729.1991.tb00230.x

11. J. K. Gilbert, in: J. K. Gilbert (Ed.): Visualization in Science Education, Springer, Dordrecht, 2005, pp. 9-27.

DOI:10.1007/1-4020-3613-2_2

12. J. K. Gilbert, M. Reiner, M. Nakhleh. Visualization: Theory and practice in science education. Springer, New York, 2008, 325 pp. DOI:10.1007/978-1-4020-5267-5

13. J. Oversby, in: J. K. Gilbert, C. J. Boulter (Eds.): Developing models in science education, Kluwer Academic Publishers, Dordrecht, 2000, pp. 227-251.

DOI:10.1007/978-94-010-0876-1_12

14. H. D. Barke, H. Wirbs, Chem. Educ. Res. Pract. 2002, 3, 185200. DOI:10.1039/B2RP90015G 
15. V. Ferk Savec, I. Sajovic, K. S. Wissiak Grm, in: J. K. Gilbert (Ed.): Multiple Representations in Chemical Education, Springer, Berlin, 2009, pp. 309-331.

DOI:10.1007/978-1-4020-8872-8_14

16. S. M. Al-Balushi, S. H. Al-Hajri, Chem. Educ. Res. Pract. 2014, 15, 47-58. DOI:10.1039/C3RP00074E

17. I. Eilks, in: V. G. Tsaparlis, H. Sevian (Eds.): Concepts of Matter in Science Education, Springer, New York, 2013, pp. 213-230. DOI:10.1007/978-94-007-5914-5_10

18. I. Devetak, J. Vogrinc, S. A. Glažar, Res. Sci. Educ. 2009, 4, 82-94.

19. S. R. Hinze, D. N. Rapp, V. M. Williamson, M. J. Shultz, G. Deslongchamps, K. C. Williamson, Learn. Instr. 2013, 26, 12-21. DOI:10.1016/j.learninstruc.2012.12.002

20. V. Ferk, M. Vrtacnik, A. Blejec, A. Gril, Int. J. Sci. Educ. 2003, 25, 1227-1245. DOI:10.1080/0950069022000038231

21. R. Kozma, J. Russell, in: J. Gilbert (Ed.): Visualization in Science Education, Kluwer, London, 2005, pp. 121-146.

DOI:10.1007/1-4020-3613-2_8

22. A. T. Stull, M. Hegarty, B. L. Dixon, M. Stieff, Cogn. Instr. 2012, 30, 404-434. DOI:10.1080/07370008.2012.719956

23. M. Stieff, S. Scopelitis, M. E. Lira, D. Desutter, Sci. Educ. 2016, 100, 344-363. DOI:10.1002/sce.21203

24. Š. Hrast, V. Ferk Savec, J. Balt. Sci. Educ. 2017, 16, in press.

25. A. Bačnik, N. Bukovec, M. Vrtačnik, A. Poberžnik, M. Križaj, V. Stefanovik, K. Sotlar, S. Dražumerič, S. Preskar, in: A. Štrukelj (Ed.): Učni načrt. Program osnovna šola. Kemija, Ministrstvo za šolstvo in šport, Zavod RS za šolstvo, Ljubljana, 2011, pp. 11.
26. A. Bačnik, N. Bukovec, M. Vrtačnik, A. Poberžnik, M. Križaj, V. Stefanovik, K. Sotlar, S. Dražumerič, S. Preskar, in: A. Štrukelj (Ed.): Učni načrt. Program osnovna šola. Kemija, Ministrstvo za šolstvo in šport, Zavod RS za šolstvo, Ljubljana, 2011, pp. 9.

27. A. Bačnik, N. Bukovec, M. Vrtačnik, A. Poberžnik, M. Križaj, V. Stefanovik, K. Sotlar, S. Dražumerič, S. Preskar, in: A. Štrukelj (Ed.): Učni načrt. Program osnovna šola. Kemija, Ministrstvo za šolstvo in šport, Zavod RS za šolstvo, Ljubljana, 2011, pp. 10.

28. K. Taber, Chemical misconceptions: Prevention, diagnosis and cure (Vol. 1), Royal Society of Chemistry, London, 2002, 246 pp.

29. H. D. Barke, A. Hazari, S. Yitbarek. Students' misconceptions and how to overcome them. Springer, Berlin, Heidelberg, 2009, pp. 21-36. DOI:10.1007/978-3-540-70989-3_3

30. V. Kind, Beyond appearances: Students' misconceptions about basic chemical ideas, School of Education, Durham University, UK, 2009, 84 pp.

31. H. Barke, N. Harsch, Afr. J. Chem. Educ. 2014, 4, 82-94.

32. V. M. Williamson, M. Hegarty, G. Deslongchamps, K. C. Williamson III, M. J. Shultz, J. Chem. Educ. 2015, 90, 159-164. DOI:10.1021/ed200259j

33. P. A. O'Keefe, S. M. Letourneau, B. D. Homer, R. N. Schwartz, J. L. Plass, Comput. Human. Behav. 2014, 35, 234-242. DOI:10.1016/j.chb.2014.02.040

34. V. Ferk Savec, Š. Hrast, I. Devetak, G. Torkar, Acta Chim. Slov. 2016, 63, 864-873. DOI:10.17344/acsi.2016.2835

\section{Povzetek}

V podporo razumevanju naravoslovnih pojmov in procesov na ravni delcev so v učna gradiva vključene različne predstavitve (reprezentacije). Članek se osredotoča na preučevanje, kako so submikroskopske reprezentacije (SMR-ji) integrirane $\mathrm{v}$ slovenske kemijske učbeniške komplete v povezavi z vsebinami učnega načrta za osnovno šolo. Izhodišče za analizo učbeniškega gradiva so predstavljali štirje holistični deskriptorji SMR-jev (direktni, indirektni, kombinirani deskriptor in SMR-ji brez deskriptorjev), ki glede na specifične opisnike SMR-jev do različne mere podpirajo učenca pri prepoznavanju informacijske vrednosti SMR-jev. Analiza učbeniških kompletov je pokazala, da se število SMR-jev močno spreminja glede na različne vsebine učnega načrta. Delež deskriptorjev, ki učencem omogočajo direktno prepoznavanje SMR-jev, je nizek v vseh vsebinah učnega načrta. Zanimivo je, da deskriptorji, ki ne omogočajo direktne prepoznave SMR-jev, prevladujejo v učbeniških kompletih. Z namenom pridobitve poglobljenega vpogleda v kriterije, na podlagi katerih avtorji učbenikov integrirajo SMR-je z različnimi deskriptorji v učbeniške komplete, so potrebne nadaljnje raziskave. 